\title{
Synthesis, Crystal and Molecular Structure of $2^{\prime}, \mathbf{3}^{\prime}, \mathbf{3}^{\prime}$-Tribromo- $2^{\prime}, 3^{\prime}$-dihydrospiro[1,3-dioxolane-2, $\mathbf{1}^{\prime}$-indene]
}

\author{
İsmail Çelik
}

Received: 25 January 2013/Accepted: 4 June 2013/Published online: 21 June 2013

(C) The Author(s) 2013. This article is published with open access at Springerlink.com

\begin{abstract}
The crystal structure of $2^{\prime}, 3^{\prime}, 3^{\prime}$-tribromo-2', $3^{\prime}$-dihydrospiro[1,3-dioxolane-2,1'-indene], $\left(\mathrm{C}_{11} \mathrm{H}_{9} \mathrm{Br}_{3} \mathrm{O}_{2}\right)$, has been determined by means of single-crystal X-ray diffraction methods. The title compound crystallizes in the monoclinic space group $P 2{ }_{1} / n$ with unit cell parameters: $a=8.9799(4), b=11.3368(8), c=12.4233(9) \AA, \beta=$ 94.938(4) $, V=1260.04(14) \AA^{3}, Z=4$. The cyclopentane ring fused to the benzene ring adopts an envelope conformation with $\mathrm{C} 11$ at the tip of the envelope. The crystal structure is stabilized by $\mathrm{C}-\mathrm{H} \cdots \mathrm{Br}$ and $\mathrm{C}-\mathrm{H} \cdots \mathrm{O}$ interactions. The $\mathrm{C}$ atoms of the $\mathrm{CH}_{2}$ groups of the 1,3-dioxolane ring, are disordered over two sites with an occupancy ratio of 0.62(7):0.38(7). A semiempirical quantum-mechanical calculation was carried out using the CNDO approximation.
\end{abstract}

Keywords Single-crystal X-ray diffraction .

Crystal structure $\cdot$ Hydrogen bonding $\cdot$ CNDO

\section{Introduction}

Indanes are important class of molecules due to the pharmacological and medicinal properties [1-4] as well as natural product chemistry [5]. Brominations of hydrocarbons are important processes in synthetic chemistry [6-10]. The materials obtained from bromination of hydrocarbons have numerous industrial applications as pesticides, plastics, fire retardants and pharmaceutical chemicals [11]. Bromoindanes are important key intermediates in the industrial and laboratory preparation of hydroxy and

İ. Çelik $(\bowtie)$

Department of Physics, Faculty of Sciences, Cumhuriyet

University, 58140 Sivas, Turkey

e-mail: icelik@cumhuriyet.edu.tr epoxide compounds [12], and of indenone and fluorenone compounds [13].

In continuation of our investigations of the synthesis and structure of the bromoindanes, we describe herein the synthesis and structure of a new compound $2^{\prime}, 3^{\prime}, 3^{\prime}$-tribromo$2^{\prime}, 3^{\prime}$-dihydrospiro[1,3-dioxolane-2, $1^{\prime}$-indene] (Scheme 1). In addition, a semiempirical quantum-mechanical calculation was carried out using the CNDO approximation. The theoretical CNDO and experimental X-ray structural results has been compared with each other.

\section{Experimental}

Synthesis

Melting points were determined on a Büchi model 530 apparatus and are uncorrected. ${ }^{1} \mathrm{H}$ and ${ }^{13} \mathrm{C}$ NMR spectra were recorded on 400 (100) $\mathrm{MHz}$ spectrometers. Mass spectra (EI) were recorded at $70 \mathrm{eV}$ as $\mathrm{m} / \mathrm{z}$. All solvents were dried and distilled before use. Column chromatography was performed on silica gel 60 (70-230 mesh, Merck). TLC was carried out on Merck $0.2 \mathrm{~mm}$ silica gel 60 F254 analytical aluminium plates. The substance reported in this paper is in its racemic form.

To a magnetically stirred solution of starting material $3^{\prime}$ bromospiro[1,3-dioxolane-2, $1^{\prime}$-indene] $(100 \mathrm{mg}, 0.4 \mathrm{mmol})$ in dichloromethane $(2 \mathrm{ml})$ at room temperature was added, dropwise, a solution of bromine $(70 \mathrm{mg}, 0,44 \mathrm{mmol})$ in dichloromethane $(0.5 \mathrm{ml})$ over the course of $1 \mathrm{~min}$. After stirring for $10 \mathrm{~min}$ at room temperature, the solvent was evaporated and the crude product, $160 \mathrm{mg}(98 \%)$ of tribromide, was crystallized from ether/hexane (3:1). m.p. 380-382 K.

${ }^{1} \mathrm{H}$ NMR $\left(400 \mathrm{MHz}, \mathrm{CDCl}_{3}\right): 7.78(\mathrm{~d}, J=7.7 \mathrm{~Hz}, \mathrm{~Hz})$, $7.55(\mathrm{td}, J=1.0 \mathrm{~Hz}, J=7.7 \mathrm{~Hz}, 2 \mathrm{H}), 7.42(\mathrm{td}, J=$ $1.0 \mathrm{~Hz}, J=7.7 \mathrm{~Hz}, 2 \mathrm{H}), 7.32(\mathrm{~d}, J=7.7 \mathrm{~Hz}, 2 \mathrm{H}), 5.06$ 


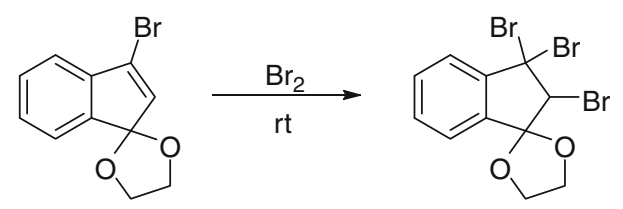

Scheme 1 Synthesis of $2^{\prime}, 3^{\prime}, 3^{\prime}$-tribromo- $2^{\prime}, 3^{\prime}$-dihydrospiro[1,3dioxolane-2, $1^{\prime}$-indene]

(s, 2H), $4.47(\mathrm{~m}, 2 \mathrm{H}), 4.37(\mathrm{~m}, 2 \mathrm{H}), 4.29(\mathrm{~m}, 2 \mathrm{H}), 4.22(\mathrm{~m}$, $2 \mathrm{H}) .{ }^{13} \mathrm{C}$ NMR $\left(100 \mathrm{MHz}, \mathrm{CDCl}_{3}\right): 145.0,136.2,131.6$, $131.1,125.8,122.9,110.9,70.5,66.83,66.78,59.6$. IR $\left(\mathrm{KBr}, \mathrm{cm}^{-1}\right): 2956,2895,1465,1316,1273,1193,1149$, 1090, 1052, 1027, 966, 948.

\section{X-Ray Structural Analysis}

Crystallographic data are given in Table 1. Pale yellow block crystal $(0.2,0.2,0.2 \mathrm{~mm})$ was used for data collection. Diffraction data for the title compound were collected at room temperature $(\mathrm{T}=294(2) \mathrm{K}$ ) using a Rigaku R-AXIS RAPID-S diffractomer with graphite monochromated Mo $\mathrm{K} \alpha$ radiation $(\lambda=0.71073 \AA$ ). The data were corrected for Lorentz-polarization and absorption effects using CrystalClear [14]. The structure was solved by the direct method using SIR97 [15] and was refined by full matrix least squares based on $F^{2}$ using SHELXL-97 [16]. The molecular graphic were drawn using the ORTEP-3 for Windows [17] and PLATON programs [18].

$\mathrm{H}$-atoms were positioned geometrically and refined using a riding model with $\mathrm{C}-\mathrm{H}=0.93$ and $0.97 \AA$, and with $\mathrm{U}_{\mathrm{iso}}(\mathrm{H})=1.2 \mathrm{U}_{\mathrm{eq}}(\mathrm{C})$. All non-hydrogen atoms were refined anisotropically. Two poorly fitted reflections (4 90 ) and (7 20 ) were omitted from the refinement. The atoms, $\mathrm{C} 1$ and $\mathrm{C} 2$, of the $-\mathrm{C}-\mathrm{C}-$ bond between the oxygen atoms in the 1,3-dioxolane ring, are disordered over two sites with site-occupancy factors of $0.62(7)$ and $0.38(7)$. In the final difference Fourier map, the highest peak is $0.86 \AA$ from atom $\mathrm{Br}_{3}$ and the deepest hole is $1.05 \AA$ from atom $\mathrm{Br}_{2}$.

\section{Results and Discussion}

\section{Crystal Structure}

As shown in the title compound, (Fig. 1), the cyclopentane ring (C4-C9) fused to the benzene ring of the nine-membered ring system (C3-C11) adopts an envelope conformation with $\mathrm{C} 11$ at the tip of the envelope [the puckering parameters [19] are $\mathrm{Q}(2)=0.330(11) \AA$ and $\left.\phi(2)=141.5(19)^{\circ}\right]$.

The $\mathrm{C}$ atoms of the $\mathrm{CH}_{2}$ groups of the 1,3-dioxolane ring, are disordered over two sites with an occupancy ratio of 0.62(7):0.38(7). In the disordered 1,3-dioxolane ring, its minor component adopts an envelope conformation with
Table 1 Crystal data and experimental details

\begin{tabular}{|c|c|}
\hline Empirical formula & $\mathrm{C}_{11} \mathrm{H}_{9} \mathrm{Br}_{3} \mathrm{O}_{2}$ \\
\hline Formula weight & 412.88 \\
\hline Temperature & 294(2) K \\
\hline Wavelength & $0.71073 \AA$ \\
\hline Crystal system & Monoclinic \\
\hline Space group & $\mathrm{P} 2{ }_{1} / \mathrm{n}$ \\
\hline Unit cell dimensions & $\begin{array}{l}\mathrm{a}=8.9799(4) \AA, \alpha=90^{\circ} \\
\mathrm{b}=11.3368(8) \AA, \beta=94.938(4)^{\circ} \\
\mathrm{c}=12.4233(9) \AA, \gamma=90^{\circ}\end{array}$ \\
\hline Volume & $1260.04(14) \AA^{3}$ \\
\hline $\mathrm{Z}$ & 4 \\
\hline Density (calculated) & $2.177 \mathrm{Mg} \mathrm{m}^{-3}$ \\
\hline Absorption coefficient & $9.59 \mathrm{~mm}^{-1}$ \\
\hline $\mathrm{F}(000)$ & 784 \\
\hline Crystal shape and color & Block, pale yellow \\
\hline Crystal size & $0.20 \times 0.20 \times 0.20 \mathrm{~mm}^{3}$ \\
\hline$\theta$ range for data collection & $2.4-26.5^{\circ}$ \\
\hline Index ranges & $\begin{array}{l}-11 \leq h \leq 11,-14 \leq k \leq 14 \\
-15 \leq l \leq 15\end{array}$ \\
\hline Reflections collected & 26249 \\
\hline Independent reflections & $2606\left[\mathrm{R}_{\mathrm{int}}=0.176\right]$ \\
\hline Completeness to $\theta=26.5^{\circ}$ & $99.8 \%$ \\
\hline Absorption correction & Multi-scan \\
\hline Max. and min. transmission & 0.250 and 0.250 \\
\hline Refinement method & Full-matrix least-squares on $F^{2}$ \\
\hline Data/restraints/parameters & $2606 / 11 / 165$ \\
\hline Calculated weights, $w$ & $\begin{array}{l}1 /\left[\sigma^{2}\left(F_{\mathrm{o}}^{2}\right)+(0.0708 P)^{2}+2.167 P\right] \\
\quad \text { where } P=\left(F_{\mathrm{o}}^{2}+2 F_{\mathrm{c}}^{2}\right) / 3\end{array}$ \\
\hline Goodness-of-fit on $F^{2}$ & 1.07 \\
\hline Final $R$ indices $[I \geq 2 \sigma(I)]$ & $\mathrm{R}_{1}=0.069, w \mathrm{R}_{2}=0.193$ \\
\hline Extinction coefficient & 0.004602 \\
\hline Largest diff. peak and hole & 0.60 and -0.91 e. $\AA^{-3}$ \\
\hline
\end{tabular}

$\mathrm{C} 3$ at the tip of the envelope [the puckering parameters are $\mathrm{Q}(2)=0.20(3) \AA$ and $\phi(2)=31(9)^{\circ} \mathrm{]}$.

In the title compound, the values of the $\mathrm{C}-\mathrm{Br}$ bond lengths range from $1.915(10)$ to $1.972(10) \AA$. The relatively wide range of the $\mathrm{Br}-\mathrm{C}-\mathrm{C}$ bond angles are within the range $108.6(7)-116.2(7)^{\circ}$ and this may indicate repulsion between the neighbouring $\mathrm{Br}$ atoms. In a related structure (1RS,2SR)-1,2,4,5,7-pentabromo-5-methoxyindane [9], the five $\mathrm{Br}-\mathrm{C}$ distances vary from $1.884(7)^{\circ}$ to $1.980(7)^{\circ} \AA$. The $\mathrm{Br}-\mathrm{C}-\mathrm{C}$ angles are within the range $107.2(5)^{\circ}$ $-117.0(4)^{\circ}$. In trans,trans,trans-2,3,5,8-tetrabromo-1,4dihydroxy-1,2,3,4-tetrahydronaphthalene [20], very similar values for the corresponding parameters [1.938(5) $\AA$ and 107.0(3)-121.6(4) ${ }^{\circ}$, respectively] were observed. All the bond lengths are within normal values (Table 1) [21].

In the crystal structure, the $\mathrm{C}-\mathrm{H} \cdots \mathrm{Br}$ and $\mathrm{C}-\mathrm{H} \cdots \mathrm{O}$ hydrogen bonding interactions (Table 2) help to stabilize 


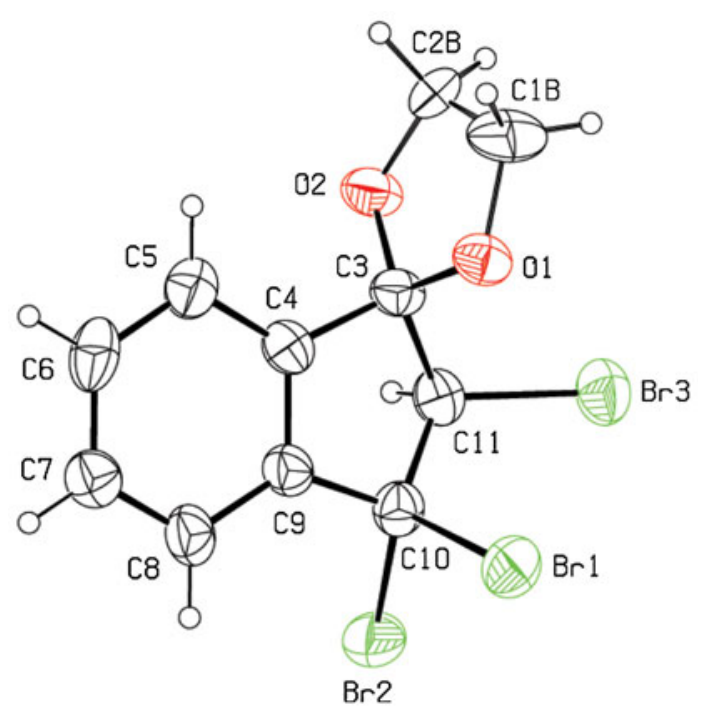

Fig. 1 Molecular structure and atomic numbering scheme for the title compound. Displacement ellipsoids for non-H atoms are drawn at the $30 \%$ probability level. Only the major components of the disordered 1,3-dioxolane ring are shown for clarity

the crystal packing of the title compound. Figure 2 shows the packing and hydrogen bonding in Table 3 of the title compound, along the a-axis.

\section{Semiempirical CNDO Calculations}

Theoretical calculations were carried out using the semiempirical quantum-mechanical complete neglect of differential overlap (CNDO) method [22]. The spatial view of the single molecule calculated as closed-shell in a vacuum is shown in Fig. 3 with atomic labels. When we compare the theoretical CNDO and experimental X-ray

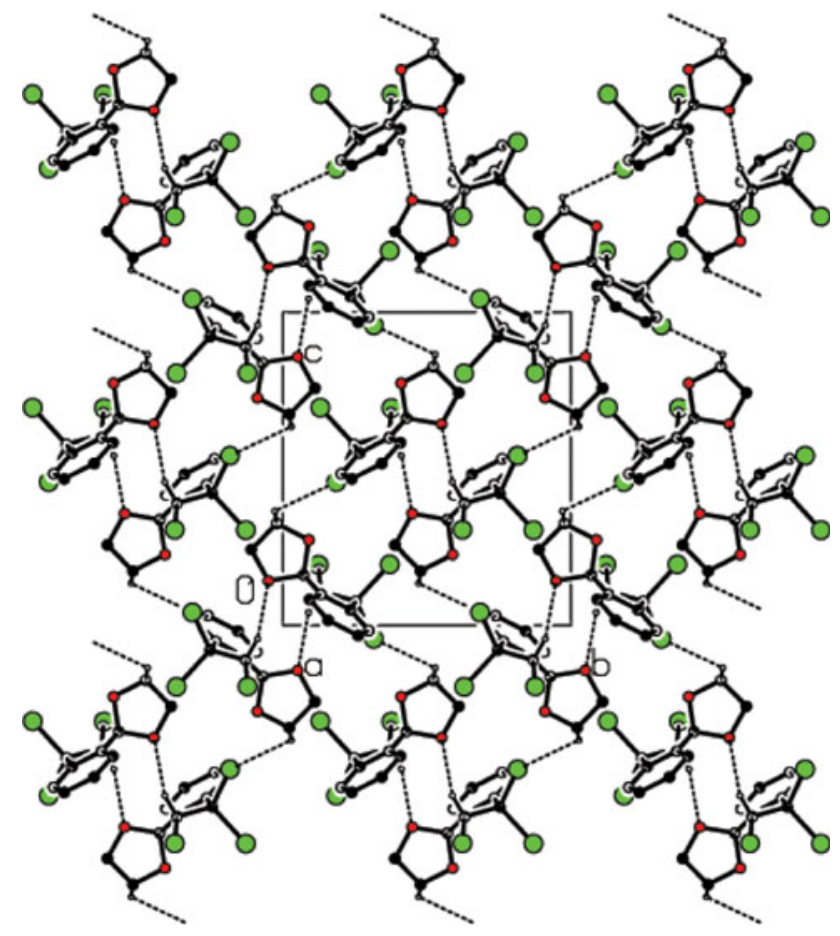

Fig. 2 View of the packing and hydrogen bonding of the title compound, along the a-axis. $\mathrm{H}$ atoms not involved in hydrogen bonding and the minor components of the disordered 1,3-dioxolane ring are omitted for the sake of clarity

structural results with each other, it is shown that due to the intermolecular interactions in the crystal structure of the title compound, the spatial configurations obtained by the theoretical CNDO and experimental X-rays for the title compound are almost the same (see Figs. 1, 3, Table 2). We may state that the theoretical calculation (based on isolated molecules) of the title compound supports the suggestion
Table 2 Selected geometric parameters $\left(\AA{ }^{\circ}\right)$

\begin{tabular}{llllll}
\hline & X-ray & CNDO & & X-ray & CNDO \\
\hline Br1-C10 & $1.972(10)$ & 2.0108 & O1-C1A & $1.44(3)$ & 1.4347 \\
Br2-C10 & $1.955(10)$ & 1.9851 & O2-C2B & $1.419(19)$ & - \\
Br3-C11 & $1.915(10)$ & 2.0966 & O2-C3 & $1.407(11)$ & 1.4189 \\
O1-C1B & $1.424(18)$ & - & O2-C2A & $1.43(3)$ & 1.4320 \\
O1-C3 & $1.402(11)$ & 1.5548 & & & \\
C1B-O1-C3 & $108.8(8)$ & - & O1-C3-C4 & $112.6(8)$ & 132.97 \\
C1A-O1-C3 & $106.6(10)$ & 113.96 & O2-C3-C4 & $112.8(8)$ & 83.03 \\
C2B-O2-C3 & $108.8(8)$ & - & O2-C3-C11 & $109.4(8)$ & 150.26 \\
C2A-O2-C3 & $106.5(10)$ & 105.28 & Br1-C10-C9 & $108.6(7)$ & 153.18 \\
O1-C1A-C2A & $106.3(19)$ & 95.95 & Br1-C10-Br2 & $106.9(5)$ & 62.48 \\
O1-C1B-C2B & $107.0(13)$ & - & Br2-C10-C11 & $110.9(7)$ & 154.92 \\
O2-C2A-C1A & $108(2)$ & 86.89 & Br1-C10-C11 & $114.4(7)$ & 92.53 \\
O2-C2B-C1B & $107.2(12)$ & - & Br2-C10-C9 & $113.4(7)$ & 92.36 \\
O1-C3-C11 & $113.7(8)$ & 87.46 & Br3-C11-C3 & $115.1(7)$ & 147.36 \\
O1-C3-O2 & $108.1(7)$ & 69.02 & Br3-C11-C10 & $116.2(7)$ & 116.74 \\
\hline
\end{tabular}


Table 3 Hydrogen-bond parameters $\left(\AA,^{\circ}\right)$

\begin{tabular}{lllll}
\hline & $D-\mathrm{H}$ & $\mathrm{H} \cdots A$ & $\mathrm{D} \cdots \mathrm{A}$ & $D-\mathrm{H} \cdots A$ \\
\hline $\mathrm{C} 1 \mathrm{~B}-\mathrm{H} 1 \mathrm{~B} 2 \cdots \mathrm{Br}^{\mathrm{i}}$ & 0.97 & 2.89 & $3.45(3)$ & 117 \\
$\mathrm{C} 11-\mathrm{H} 11 \cdots \mathrm{O} 2^{\mathrm{ii}}$ & 0.98 & 2.55 & $3.363(12)$ & 140 \\
\hline
\end{tabular}

Symmetry codes: (i) $1 / 2+\mathrm{x}, 1 / 2-\mathrm{y}, 1 / 2+\mathrm{z}$; (ii) $1-\mathrm{x},-\mathrm{y},-\mathrm{z}$

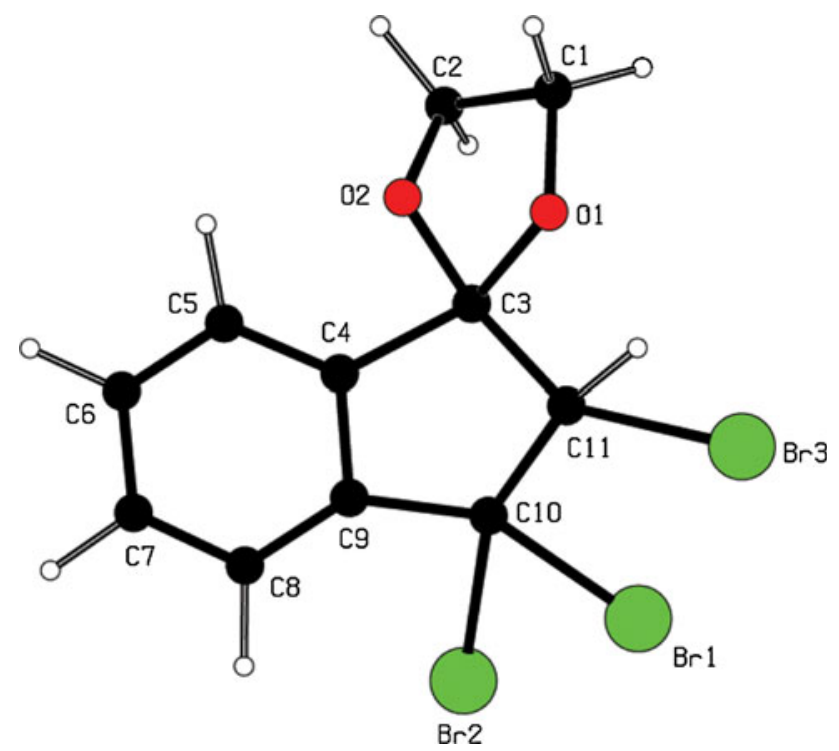

Fig. 3 The spatial view of the title molecule (I), calculated by the CNDO approximation

that the present intra and intermolecular interactions in the title compound influence crystal packing. The HOMO and LUMO energy levels of the title compound are -4.1128 and $0.8545 \mathrm{eV}$, respectively. Its calculated molecule dipole moment is 8.507 Debye $\left(1 \mathrm{D}=3.33564 \times 10^{-30}\right.$ C.m. $)$. The charges at atoms $\mathrm{C} 10, \mathrm{C} 11, \mathrm{O} 1, \mathrm{O} 2, \mathrm{Br} 1, \mathrm{Br} 2$ and $\mathrm{Br} 3$ are $-0.3025,-0.3029,0.0535,0.1285,0.2418,0.1724$ and $-0.5880 \mathrm{e}^{-}$, respectively.

\section{Supplementary Material}

CCDC 917443 contain the supplementary crystallographic data for this paper. These data can be obtained free of charge from The Cambridge Crystallographic Data Centre via www.ccdc.cam.ac.uk/data_resquest/cif.

Acknowledgments The author thanks Prof. Dr. A. Daştan, Atatürk University, Erzurum, for the gift sample of the title compound.

Open Access This article is distributed under the terms of the Creative Commons Attribution License which permits any use, distribution, and reproduction in any medium, provided the original author(s) and the source are credited.

\section{References}

1. Mitrochkine A, Eydoux F, Martres M, Gil G, Heumann A, Reglier M (1995) Tetrahedron Asymmetry 6:59-62

2. Catto M, Aliano R, Carotti A, Cellamare S, Palluotto F, Purgatorio R, Stradis AD, Campagna F (2010) Eur J Med Chem 45: $1359-1366$

3. Wu YJ (2006) Tetrahedron Lett 47:8459-8461

4. McClure KJ, Maher M, Wu N, Chaplan SR, Erkert WA, Lee DH, Wickenden AD, Hermann M, Allison B, Hawryluk N, Breitenbucher GJ, Grice CA (2011) Bioorg Med Chem Lett 21:5197-5201

5. Snyder SA, Brill ZG (2011) Org Lett 13:5524-5527

6. Çakmak O, Erenler R, Tutar A, Çelik N (2006) J Org Chem 71:1795-1801

7. Erenler, R., Demirtas, I., Büyükkidan, B. , Çakmak, O. (2006). J. Chem. Res. pp. 753-757

8. Erenler R, Çakmak O (2004) J Chem Res 68:566-569

9. Akkurt M, Çelik İ, Berkil K, Tutar A, Ersanlı CC, Çakmak O, Büyükgüngör O (2005) Acta Crystallogr E 61:0475-0477

10. Çelik İ, Akkurt M, Yılmaz M, Tutar A, Erenler R, Kazak C (2012) Acta Crystallogr E 68:o1884

11. Hileman B (1993) Chem Eng News 19:11-13

12. Crosman A, Gelbard G, Poncelet G, Porvulescu VI (2004) Appl Catal A 264:23-32

13. Tutar A, Çakmak O, Balci M (2001) Tetrahedron 57:9759-9763

14. Rigaku/MSC (2005) Crystalclear. Rigaku/MSC, The Woodlands

15. Altomare A, Burla MC, Camalli M, Cascarano GL, Giacovazzo C, Guagliardi A, Moliterni AGG, Polidori G, Spagna R (1999) J Appl Crystallogr 32:115

16. Sheldrick GM (2008) Acta Crystallogr A 64:112

17. Farrugia LJ (1997) J Appl Crystallogr 30:565

18. Spek AL (2009) Acta Crystallogr D 65:148-155

19. Cremer D, Pople JA (1975) J Am Chem Soc 97:1354

20. Akkurt M, Çelik I, Erenler R, Çakmak O, Ersanli CC, Büyükgüngör O (2004) Acta Crystallogr E 60:02096

21. Allen FH, Kennard O, Watson DG, Brammer L, Orpen AG, Taylor R (1987) J Chem Soc Perkin Trans 2:S1-S19

22. Pople JA, Beveridge DL (1970) Approximate molecular orbital theory. McGraw-Hill, New York 